\title{
Impact of Yeast Selection on Volatile Phenol Levels of Wines Produced from Smoked-Exposed Juice
}

\author{
Heinrich W. du Plessis ${ }^{1, *\left(\mathbb{D} \text {, Justin W. Hoff }{ }^{1} \text {, Lucky Mokwena }\right.}{ }^{2}$, Marieta van der Rijst ${ }^{3}$ and Neil P. Jolly ${ }^{1}$ \\ 1 Post-Harvest and Agro-Processing Technologies, Agricultural Research Council (ARC) Infruitec-Nietvoorbij, \\ Private Bag X5026, Stellenbosch 7599, South Africa; hoffjw@arc.agric.za (J.W.H.); jollyn@arc.agric.za (N.P.J.) \\ 2 Central Analytical Facilities, Stellenbosch University, Private Bag X1, Matieland 7602, South Africa; \\ mokwenal@sun.ac.za \\ 3 ARC Biometry, Private Bag X5026, Stellenbosch 7599, South Africa; VanDerRijstM@arc.agric.za \\ * Correspondence: dplessishe@arc.agric.za; Tel.: +27-021-809-3063
}

Citation: du Plessis, H.W.; Hoff, J.W.; Mokwena, L.; van der Rijst, M.; Jolly, N.P. Impact of Yeast Selection on Volatile Phenol Levels of Wines Produced from Smoked-Exposed Juice. Fermentation 2021, 7, 240. https://doi.org/10.3390/

fermentation7040240

Academic Editor: Niel van Wyk

Received: 29 July 2021

Accepted: 25 September 2021

Published: 26 October 2021

Publisher's Note: MDPI stays neutral with regard to jurisdictional claims in published maps and institutional affiliations.

Copyright: (c) 2021 by the authors. Licensee MDPI, Basel, Switzerland. This article is an open access article distributed under the terms and conditions of the Creative Commons Attribution (CC BY) license (https:/ / creativecommons.org/licenses/by/ $4.0 /)$.

\begin{abstract}
Grapes exposed to smoke can result in wines that have unacceptable high levels of volatile phenols. High volatile phenols levels have a negative impact on wine quality. This study aimed to determine the levels of volatile phenols in wines produced from smoke-exposed juice by a selection of commercial wine yeasts and to determine if yeast selection affected the perception of smokiness in wine. Commercial white and red wine yeasts were screened for the production of volatile phenols in smoke-exposed Chenin Blanc and Merlot juice. Volatile phenol levels were determined by GCMS/MS and wines were also subjected to sensory evaluation. Volatile phenol levels in smoked wines varied and was affected by yeast strain. The highest guaiacol levels in Chenin Blanc were found in wines fermented with QA23, while Merlot wines that underwent spontaneous alcoholic fermentation contained the highest levels. The levels of volatile phenols differed significantly between the smoked and unsmoked wines, and the sensory results supported the chemical data. Volatile phenols had a negative effect on Chenin Blanc flavor profiles even when the levels were below odor detection thresholds. Yeast selection is important and can affect the volatile phenol levels and flavor profiles of wines.
\end{abstract}

Keywords: yeasts; smoke; chemical analyses; volatile phenols; sensory evaluation; wine

\section{Introduction}

The occurrence of wildfires and the incidence of smoke exposure in vineyards seem to be increasing. Several wine-producing countries (Australia, United States of America, Chile, Spain, Portugal, Greece, Italy, France and South Africa) have been affected by fire or smoke damage to vineyards [1]. Australia and USA in particular suffered substantial losses in revenue due to fire and smoke damage [2,3]. Grapevines and grapes exposed to smoke from fires can result in smoke-tainted wines [4,5]. Wines produced from smoke-exposed grapes can have unpleasant burnt, medicinal, smoky and ashy characteristics, collectively known as "smoke taint" [4-6]. Factors such as timing and duration of smoke exposure [7], phenological stage of the grapes [8], grape maturity stage [9], grape variety [10], as well as winemaking practices [11,12] can affect the intensity of smoke taint. Wines produced from white grape varieties have fewer smoke-related sensory and chemical faults due to the reduced contact time on skins during fermentation compared to red wine [1].

The presence of smoke taint in wine can be determined chemically by measuring the concentrations of smoke-derived volatile phenols, such as guaiacol, 4-methylguaiacol, $o-, m$ - and $p$-cresol, syringol and 4-methylsyringol, as well as sensory analysis $[4,10,13]$. Kennison et al. [5] were the first to report the increase of smoke-derived volatile phenols, in glycoconjugate form, during alcoholic and malolactic fermentation. These authors also reported trace levels of guaiacol, 4-methylguaiacol, 4-ethylguaiacol and 4-ethylphenol in free-run juice obtained from smoke-exposed grapes, which significantly increased during 
fermentation, or when hydrolyzed with strong acid or $\beta$-glucosidase enzymes. Guaiacol imparts a smoky, burnt character and has the lowest aroma detection threshold of the volatile phenols [14].

Yeasts present on grapes and winery equipment or added as starter cultures [15] are responsible for transforming grape must into wine through alcoholic fermentation. Yeasts also contribute to wine flavor and quality through the production and excretion of metabolites [16]. While many of the early knowledge gaps about the effect of smoke on grape and wine composition have been investigated, only Ristic et al. [11] reported on the effect of yeast selection on the concentration and sensory impact of smoke-derived volatiles in wine. Ristic et al. [11] investigated the varying ability of eight yeast strains to affect the concentration of volatile phenols and sensory profiles of Grenache wines, and proposed that selected yeast strains could be used to alter smoke-related aromas, flavors, color and chemical composition of wines. The occurrence of wildfires are unpredictable so the source of naturally smoke affected grapes is limited. During smoke trials, vines and grapes are usually smoked in purpose built tents, where smoke is then pumped into these enclosures $[4,5,11]$. To circumvent these logistical limitations of smoking the grapes on the vine, this study exposed the grape juice to smoke and fermented with various yeast strains. The aims of this study were to determine if there were differences in the volatile phenol levels in wines fermented with the selected commercial white and red wine yeasts, and to ascertain if yeast selection could change or mask the perception of smokiness in wine prepared from smoke-exposed juice. This was accomplished by measuring volatile phenol marker compounds and conducting sensory evaluations.

\section{Materials and Methods}

Laboratory-scale fermentation trials were performed in smoked-exposed Chenin Blanc and Merlot juice to screen a range of commercial yeasts. This was accompanied by a small-scale wine production trial in smoked and unsmoked Chenin Blanc juice with a sub-selection of three yeasts.

\subsection{Yeast Strains}

For laboratory-scale Chenin blanc trial, the following commercial white wine yeasts were used: Saccharomyces cerevisiae Lalvin ICV BM4x4, Lalvin QA23 ${ }^{\mathrm{TM}}$, Lalvin Rhône $4600^{\mathrm{TM}}$, Cross Evolution ${ }^{\mathrm{TM}}$ (Lallemand, Cape Town, South Africa), AWRI R2 (Mauri Yeast Australia, Toowoomba, Australia), Alchemy II, VIN 7, VIN 13 (Anchor Yeast, Cape Town, South Africa), UOA Maxithiol (Mauri Yeast, Toowoomba, Australia), Zymaflore ${ }^{\circledR}$ X5 and Zymaflore ${ }^{\circledR}$ X16 (Laffort, Paarl, South Africa). Enoferm BDX ${ }^{\mathrm{TM}}$ (Lallemand) was used as a reference yeast. Merlot wines were produced with the following red wine yeasts: Saccharomyces cerevisiae Enoferm BDX ${ }^{\mathrm{TM}}$, Lalvin Clos $^{\mathrm{TM}}$, Lalvin ICV D21, Lalvin ICV D254 ${ }^{\mathrm{TM}}$, Lalvin ICV D80 ${ }^{\mathrm{TM}}$, Lalvin QA23 ${ }^{\mathrm{TM}}$, Uvaferm Exence ${ }^{\mathrm{TM}}$ (Lallemand), NT 50, NT 112, NT 202, VIN 13, WE 372 (Anchor Yeast), AWRI 796 (Maurivin), Zymaflore ${ }^{\circledR}$ FX10 and Zymaflore ${ }^{\circledR}$ RX60 (Laffort). Only three yeast were used in the small-scale Chenin Blanc wine production trial: QA23, VIN 13 and X16. The active dried wine yeasts were rehydrated and inoculated according to the recommendations of the respective manufacturers'. Yeasts were selected based on their availability to South African wine producers.

\subsection{Preparation of Smoked Juice}

Chenin Blanc grapes from Nietvoorbij research farm (Stellenbosch, South Africa) were harvested at $22.2{ }^{\circ} \mathrm{Brix}$, destemmed, crushed and $\mathrm{SO}_{2}$ added at $50 \mathrm{mg} / \mathrm{L}$. The freerun juice was treated with $0.5 \mathrm{~g} / \mathrm{L}$ Ultrazyme (Novozymes, Bagsværd, Denmark) and allowed to sediment overnight at $14{ }^{\circ} \mathrm{C}$. After racking the homogenous clarified juice $( \pm 260 \mathrm{~L})$ was split into two equal portions. The one portion $( \pm 130 \mathrm{~L})$ received no smoke (control/reference) and the other portion $( \pm 130 \mathrm{~L})$ was exposed to smoke in a $300 \mathrm{~L}$ stainless steel fermentation tank, with glass observation panel on the side, using a standard beehive smoker. Selected fynbos (Leucadendron salignum, Leucadendron spissifolium, Protea repens) 
and pine (Pinus radiata) plant material was used as smoke source. Smoke was blown into the fermentation tank, until it was completely filled as viewed through the observation pane. The juice surface area of $0.24 \mathrm{~m}^{2}$ was exposed to smoke and left in contact with the smoke for $1 \mathrm{~h}$ with no agitation. This was followed by a thorough mixing of the juice before aliquots of $14 \mathrm{~L}$ were divided into nine stainless steel containers $(20 \mathrm{~L})$. A portion of the smoked juice was kept aside for the laboratory-scale trials.

Merlot grapes also from the Nietvoorbij research farm, were harvested at $24.6^{\circ}$ Brix, destemmed, crushed and the skins separated from the juice. The same smoking procedure was applied to the Merlot juice as described for Chenin Blanc juice. No settling enzyme was added and only a portion of juice used for the laboratory-scale trial.

\subsection{Laboratory-Scale Yeast Trials}

The Chenin Blanc trial investigated yeast performance under white wine production conditions, while the Merlot trial simulated red wine conditions.

In the Chenin Blanc yeast trial, the 12 commercial Saccharomyces cerevisiae white wine yeast strains $(0.3 \mathrm{~g} / \mathrm{L})$ were rehydrated and inoculated into $200 \mathrm{~mL}$ smoked juice in sterile glass bottles. Di-ammonium phosphate (DAP) was added at a dosage of $0.50 \mathrm{~g} / \mathrm{L}$ to ensure nitrogen limitation would not occur. Yeast assimilable nitrogen (YAN) was $179 \mathrm{mg} / \mathrm{L}$. The juice was fermented at ambient temperature of $15^{\circ} \mathrm{C}$ and the bottles were closed with fermentation locks containing distilled $\mathrm{H}_{2} \mathrm{O}$. A spontaneous fermentation treatment was also included and received no yeast inoculum. Each yeast treatment, as well as the spontaneous fermentation had three replicates. Bottles were weighed daily to determine $\mathrm{CO}_{2}$ mass loss. Bottles were weighed prior to sampling and after sampling. Samples were taken every 3-4 days for routine chemical analyses and volatile phenol samples were collected at the end of alcoholic fermentation and stored at $4{ }^{\circ} \mathrm{C}$ until analyzed.

The Merlot yeast trial was conducted in a similar manner to the Chenin Blanc trial, but with 15 commercial red wine yeast strains and the fermentation temperature was ca. $24^{\circ} \mathrm{C}$. The YAN of the Merlot juice was $131 \mathrm{mg} / \mathrm{L}$. A spontaneous fermentation treatment was also included. Each yeast treatment, as well as the spontaneous fermentation had three replicates.

\subsection{Small-Scale Wine Production Trial}

In the small-scale wine production trial, three yeast strains (QA23, VIN 13 and X16) were compared in smoked and unsmoked Chenin Blanc juice and each treatment had three replicates. The unsmoked juice served as the control treatment. The stainless steel containers were fitted with fermentation locks and DAP was added at a dosage of $0.50 \mathrm{~g} / \mathrm{L}$. Fermentations were conducted at an ambient temperature of ca. $15^{\circ} \mathrm{C}$ and monitored by $\mathrm{CO}_{2}$ mass loss. Towards the end of fermentation the residual sugar levels were measured (Density Meter DMA35, Anton Paar, Graz, Austria) and those showing no further reduction in residual sugar were racked off the yeast lees. The free $\mathrm{SO}_{2}$ was adjusted to $35 \mathrm{mg} / \mathrm{L}$, a bentonite solution $(0.75 \mathrm{~g} / \mathrm{L})$ added and the wines were cold stabilized at $0{ }^{\circ} \mathrm{C}$ for at least two weeks. The wines were filtered through a $0.45 \mu \mathrm{m}$ membrane filter and bottled under nitrogen gas in $750 \mathrm{~mL}$ glass bottles. The bottles were closed with screw caps. The wines were stored at $14{ }^{\circ} \mathrm{C}$ until analyzed.

\subsection{Chemical Analyses}

Enological parameters, such as residual sugar (glucose + fructose), $\mathrm{pH}$, malic acid, total acidity (TA), ethanol and volatile acidity (VA) of the wines were determined with an OenoFoss $^{\mathrm{TM}}$ wine analyzer (FOSS Analytical A/S, Hillerød, Denmark). Alcoholic fermentation was monitored and considered complete when the residual sugar concentrations were below $4 \mathrm{~g} / \mathrm{L}$.

Juice and wine samples were analyzed for volatile phenol content using a GC-MS/MS. The method described by de Vries [17] and McKay et al. [18] was applied with some modifications. Briefly, ten milliliters of the wine was transferred into a solid phase micro 
extraction (SPME) vial. Five milliliters of a $20 \%$ sodium chloride solution was added into the vial and vortexed. Anisole $\mathrm{d}_{8}$ was added as internal standard. The headspace of the sample was analyzed using a PDMS/DVB fiber. Analysis was performed on a Thermo Scientific TRACETM 1310 gas chromatograph automated injection coupled to TSQ 8000 MS/MS Triple Quadrupole chromatograph (Anatech Instruments (Pty) Ltd, Cape Town, South Africa). Separation was obtained with a polar ZBwax $(30 \mathrm{~m}, 0.25 \mathrm{~mm}$ ID, $0.25 \mu \mathrm{m}$ film thickness) capillary column. The mass spectrometer was operated in MS/MS mode. The ionization source temperature was set at $250{ }^{\circ} \mathrm{C}$ and emission current of $50 \mu \mathrm{A}$ was used with argon as collision gas.

Ten volatile phenols were quantified: guaiacol, 2,6-dimethyl phenol (2,6-DMP), 4methylguaiacol (4-MG), $o$-cresol, phenol, 4-ethylguaiacol (4-EG), $m$-cresol, $p$-cresol, 2,3dimethylphenol (2,3-DMP), eugenol, 4-ethylphenol (4-EP) and 3,4-dimethylphenol (3,4-DMP).

\subsection{Sensory Evaluations}

Triangle testing of Chenin Blanc wines was carried out by a panel of 18 judges (10 men and eight women, aged 22-60 years). The wine judges did not receive prior training. The judges had to choose "the odd one out" from the three wines presented and had to indicate which wine they preferred. They could also comment on the sensory profile of the wines. The three replicates of each treatment were pooled prior to the tasting. Each judge was seated in a separate tasting booth and ca. $30 \mathrm{~mL}$ of the wine sample was presented in a randomized order in a standard international wine tasting glass, labeled with a random three-digit code.

\subsection{Data and Statistical Analysis}

Chemical data were subjected to analysis of variance (ANOVA) and principal component analysis (PCA) using XLSTAT software (Version18.07.39157, Addinsoft, New York, NY, USA). Fisher's least significant difference (LSD) values were calculated at the $5 \%$ probability level $(p=0.05)$ to facilitate comparison between treatment means. The sensory results were analyzed using a triangular testing program described by Randall [19] for wine and brandy evaluation. The probability values were also compared to those in tables compiled by Roessler et al. [20].

\section{Results and Discussion}

Wildfire events are unpredictable and sourcing smoke-affected grapes for research are not always possible. Smoking the grapes on the vines is not always practically possible and constructing a structure for this purpose has its own limitations (difficult, expensive, small area or selective vines exposed). Therefore, this study opted for smoking the juice as an easier method to investigate the yeast-drive changes in smoke-associated compounds that occurred during fermentation. Cognizance is taken that this method only measured the volatile phenols and not glycoconjugated phenols. However, this method has the potential to allow the screening of a large number of yeasts, and because the juice can be frozen, it is not limited to the harvest.

\subsection{Standard Chemical Parameters of Wines \\ 3.1.1. Laboratory-Scale Yeast Trials}

The selected yeast strains showed minor differences with regard to fermentation speed and $\mathrm{CO}_{2}$ weight loss (data not shown). The residual sugar levels, alcohol content, $\mathrm{pH}, \mathrm{TA}$, malic acid and VA of laboratory-scale Chenin Blanc wines are reported in Table 1. All wines fermented to dryness (residual sugar $<4 \mathrm{~g} / \mathrm{L}$ ) as per South African legislation [21]. In the yeast selection trial, the ethanol content ranged from $12.3 \%$ to $13.5 \%(v / v)$ in the smoked wines, with the spontaneous fermentation containing significantly $(p<0.0001)$ higher levels than most of the other yeast treatments. The TA and VA levels differed significantly $(p<0.0001)$ among wines produced with different yeasts. TA measured between 6.2 
and $6.9 \mathrm{~g} / \mathrm{L}$, and VA ranged between 0.2 and $0.5 \mathrm{~g} / \mathrm{L}$. It is, thus, apparent that the yeast treatment had a significant effect on the various chemical parameters.

Table 1. Enological parameters and probability $(p)$ values of laboratory-scale Chenin Blanc wines produced from smoked juice using different commercial wine yeasts.

\begin{tabular}{|c|c|c|c|c|c|c|}
\hline Treatment & $\begin{array}{c}\text { Residual Sugar } \\
(\mathrm{g} / \mathrm{L})\end{array}$ & $\begin{array}{l}\text { Ethanol } \\
(\% v / v)\end{array}$ & $\mathrm{pH}$ & $\begin{array}{c}\text { Total Acidity } \\
\text { (g/L) }\end{array}$ & $\begin{array}{l}\text { Malic Acid } \\
\text { (g/L) }\end{array}$ & $\begin{array}{c}\text { Volatile } \\
\text { Acidity (g/L) }\end{array}$ \\
\hline QA 23 & $0.8 \pm 0.49 \mathrm{~cd}$ & $13.2 \pm 0.09 \mathrm{bcd}$ & $3.40 \pm 0.01^{b c}$ & $6.6 \pm 0.05^{c}$ & $1.7 \pm 0.05^{\mathrm{ab}}$ & $0.44 \pm 0.02^{b c}$ \\
\hline$\widehat{\mathrm{BM}} 4 \times 4$ & $0.4 \pm 0.49^{\mathrm{d}}$ & $13.1 \pm 0.09 \mathrm{bcd}$ & $3.36 \pm 0.01$ cde & $6.2 \pm 0.05^{\mathrm{e}}$ & $1.6 \pm 0.05^{\text {bcde }}$ & $0.30 \pm 0.02 \mathrm{fg}$ \\
\hline AWRI R2 & $1.2 \pm 0.49 \mathrm{bcd}$ & $12.5 \pm 0.09 \mathrm{gh}$ & $3.27 \pm 0.01^{g}$ & $6.9 \pm 0.05^{\mathrm{a}}$ & $1.8 \pm 0.05^{\mathrm{a}}$ & $0.33 \pm 0.02$ ef \\
\hline Rhone 4600 & $0.5 \pm 0.49^{\mathrm{cd}}$ & $12.8 \pm 0.09$ ef & $3.34 \pm 0.01$ def & $6.4 \pm 0.05^{\mathrm{d}}$ & $1.7 \pm 0.05^{\mathrm{ab}}$ & $0.35 \pm 0.02^{\mathrm{e}}$ \\
\hline Cross evol. ${ }^{1}$ & $1.7 \pm 0.49^{b c d}$ & $13.0 \pm 0.09$ bcde & $3.38 \pm 0.01^{\mathrm{cd}}$ & $6.3 \pm 0.05^{\mathrm{e}}$ & $1.5 \pm 0.05^{\mathrm{de}}$ & $0.26 \pm 0.02 \mathrm{~g}$ \\
\hline Alchemy II & $1.3 \pm 0.49^{b c d}$ & $12.9 \pm 0.09 \mathrm{de}$ & $3.46 \pm 0.01^{\mathrm{a}}$ & $6.8 \pm 0.05^{\mathrm{ab}}$ & $1.6 \pm 0.05^{\mathrm{bcd}}$ & $0.53 \pm 0.02^{\mathrm{a}}$ \\
\hline VIN 7 & $1.9 \pm 0.49^{b c d}$ & $13.1 \pm 0.09 \mathrm{bcd}$ & $3.34 \pm 0.01^{\mathrm{def}}$ & $6.2 \pm 0.05^{\mathrm{e}}$ & $1.6 \pm 0.05^{\text {bcde }}$ & $0.17 \pm 0.02^{h}$ \\
\hline Spon $\mathrm{AF}^{2}$ & $2.5 \pm 0.60^{\mathrm{ab}}$ & $13.5 \pm 0.11^{\mathrm{a}}$ & $3.32 \pm 0.02^{\mathrm{f}}$ & $6.9 \pm 0.06^{\mathrm{a}}$ & $1.5 \pm 0.06^{\mathrm{de}}$ & $0.35 \pm 0.02$ ef \\
\hline BDX & $1.9 \pm 0.49 b c$ & $13.2 \pm 0.09 \mathrm{abc}$ & $3.31 \pm 0.01^{\mathrm{f}}$ & $6.5 \pm 0.05^{\mathrm{d}}$ & $1.5 \pm 0.05^{\mathrm{cde}}$ & $0.30 \pm 0.02 \mathrm{fg}$ \\
\hline UOA Maxi ${ }^{3}$ & $0.6 \pm 0.49^{\mathrm{cd}}$ & $12.6 \pm 0.09 \mathrm{fg}$ & $3.34 \pm 0.01$ def & $6.7 \pm 0.05^{b c}$ & $1.6 \pm 0.05$ bcde & $0.46 \pm 0.02^{b}$ \\
\hline$X 5$ & $1.3 \pm 0.49^{b c d}$ & $13.3 \pm 0.09^{a b}$ & $3.33 \pm 0.01$ ef & $6.6 \pm 0.05^{\mathrm{c}}$ & $1.7 \pm 0.05^{\mathrm{ab}}$ & $0.40 \pm 0.02^{\mathrm{cd}}$ \\
\hline VIN 13 & $3.4 \pm 0.60^{\mathrm{a}}$ & $12.3 \pm 0.11^{h}$ & $3.44 \pm 0.02^{a b}$ & $6.8 \pm 0.06^{\mathrm{a}}$ & $1.7 \pm 0.06^{\mathrm{abc}}$ & $0.37 \pm 0.02 \mathrm{de}$ \\
\hline X16 & $3.4 \pm 0.49^{a}$ & $13.0 \pm 0.09$ cde & $3.40 \pm 0.01^{b c}$ & $6.3 \pm 0.05^{\mathrm{e}}$ & $1.5 \pm 0.05^{\mathrm{e}}$ & $0.30 \pm 0.02 \mathrm{fg}$ \\
\hline$p$ & 0.003 & $<0.0001$ & $<0.0001$ & $<0.0001$ & 0.002 & $<0.0001$ \\
\hline
\end{tabular}

${ }^{1}$ Cross evolution, ${ }^{2}$ spontaneous alcoholic fermentation, ${ }^{3}$ UOA Maxithiol (details about the yeast strains can be found in the materials and methods). Each value represents the mean of three replicates ( \pm standard error of the mean). Means in columns followed by different letters are significantly different $(p \leq 0.05)$.

Table 2. Enological parameters and probability $(p)$ values of Merlot wines produced from smoke-exposed juice using different commercial wine yeasts.

\begin{tabular}{|c|c|c|c|c|c|c|}
\hline Treatment & $\begin{array}{c}\text { Residual Sugar } \\
(\mathrm{g} / \mathrm{L})\end{array}$ & $\begin{array}{l}\text { Ethanol } \\
(\% v / v)\end{array}$ & $\mathrm{pH}$ & $\begin{array}{c}\text { Total Acidity } \\
\text { (g/L) }\end{array}$ & $\begin{array}{l}\text { Malic Acid } \\
\text { (g/L) }\end{array}$ & $\begin{array}{c}\text { Volatile } \\
\text { Acidity (g/L) }\end{array}$ \\
\hline Spon $\mathrm{AF}^{1}$ & $21.4 \pm 1.53^{a}$ & $14.9 \pm 0.13^{\mathrm{abc}}$ & $3.84 \pm 0.01^{a}$ & $5.4 \pm 0.07 \mathrm{bc}$ & $2.3 \pm 0.15^{\mathrm{a}}$ & $0.28 \pm 0.02{ }^{a b c d}$ \\
\hline D254 & $3.3 \pm 1.53^{\mathrm{cd}}$ & $14.4 \pm 0.13^{\text {efg }}$ & $3.77 \pm 0.01^{\operatorname{defg}}$ & $4.9 \pm 0.07$ ghi & $1.8 \pm 0.15^{\mathrm{d}}$ & $0.33 \pm 0.02^{\mathrm{a}}$ \\
\hline Exence & $2.1 \pm 1.53^{\mathrm{d}}$ & $14.7 \pm 0.13^{\text {abcde }}$ & $3.79 \pm 0.01$ bcde & $5.0 \pm 0.07$ fghi & $1.8 \pm 0.15^{\mathrm{cd}}$ & $0.25 \pm 0.02$ cdef \\
\hline D21 & $3.8 \pm 1.53^{\mathrm{cd}}$ & $14.8 \pm 0.13^{\mathrm{abcd}}$ & $3.80 \pm 0.01^{a b c}$ & $4.9 \pm 0.07 \mathrm{hi}$ & $1.9 \pm 0.15^{\mathrm{bcd}}$ & $0.22 \pm 0.02$ ef $^{-1}$ \\
\hline NT 50 & $1.6 \pm 1.53^{\mathrm{d}}$ & $14.6 \pm 0.13^{\text {cdefg }}$ & $3.80 \pm 0.01 \mathrm{bcd}$ & $5.1 \pm 0.07^{\text {efgh }}$ & $1.9 \pm 0.15^{b c d}$ & $0.31 \pm 0.02 \mathrm{ab}$ \\
\hline Clos & $6.3 \pm 1.53 \mathrm{bcd}$ & $14.45 \pm 0.13^{\operatorname{defg}}$ & $3.77 \pm 0.01^{\text {cdef }}$ & $5.1 \pm 0.07^{\text {efgh }}$ & $2.1 \pm 0.15^{\mathrm{abcd}}$ & $0.25 \pm 0.02$ cdef \\
\hline QA 23 & $2.7 \pm 1.53^{\mathrm{cd}}$ & $15.1 \pm 0.15^{\mathrm{a}}$ & $3.80 \pm 0.01 \mathrm{bcd}$ & $5.1 \pm 0.07^{\text {efgh }}$ & $1.8 \pm 0.15^{\mathrm{d}}$ & $0.30 \pm 0.02 \mathrm{abc}$ \\
\hline AWRI 796 & $3.4 \pm 1.53^{\mathrm{cd}}$ & $14.7 \pm 0.13^{\text {abcde }}$ & $3.71 \pm 0.01^{\mathrm{h}}$ & $5.5 \pm 0.07^{\mathrm{b}}$ & $2.3 \pm 0.15^{\mathrm{ab}}$ & $0.29 \pm 0.02^{\mathrm{abcd}}$ \\
\hline BDX & $4.3 \pm 1.53^{\mathrm{cd}}$ & $14.9 \pm 0.13^{a b c}$ & $3.82 \pm 0.01^{a b}$ & $5.1 \pm 0.07^{\text {efgh }}$ & $2.3 \pm 0.15^{a b c}$ & $0.23 \pm 0.02$ def \\
\hline D80 & $3.9 \pm 1.53^{\mathrm{cd}}$ & $14.2 \pm 0.13 \mathrm{~g}$ & $3.79 \pm 0.01$ bcde & $4.8 \pm 0.07^{\mathrm{i}}$ & $2.0 \pm 0.15^{\mathrm{abcd}}$ & $0.27 \pm 0.02$ bcde \\
\hline FX10 & $3.9 \pm 1.53^{\mathrm{cd}}$ & $14.7 \pm 0.13^{\text {abcde }}$ & $3.76 \pm 0.01$ efg & $5.1 \pm 0.07^{\text {defg }}$ & $2.0 \pm 0.15^{\mathrm{abcd}}$ & $0.20 \pm 0.02^{f}$ \\
\hline NT 202 & $1.8 \pm 1.53^{\mathrm{d}}$ & $14.6 \pm 0.13^{\text {bcdef }}$ & $3.72 \pm 0.01^{h}$ & $5.3 \pm 0.07^{\mathrm{bcd}}$ & $2.1 \pm 0.15^{\mathrm{abcd}}$ & $0.20 \pm 0.02^{f}$ \\
\hline VIN 13 & $3.7 \pm 1.53^{\mathrm{cd}}$ & $14.6 \pm 0.13^{\text {bcdef }}$ & $3.78 \pm 0.01$ cde & $5.2 \pm 0.07^{\mathrm{def}}$ & $2.0 \pm 0.15^{\mathrm{abcd}}$ & $0.30 \pm 0.02^{a b c}$ \\
\hline WE 372 & $9.2 \pm 1.53^{b}$ & $14.3 \pm 0.13^{\mathrm{fg}}$ & $3.73 \pm 0.01 \mathrm{gh}$ & $5.9 \pm 0.07^{\mathrm{a}}$ & $2.2 \pm 0.15^{\mathrm{abcd}}$ & $0.27 \pm 0.02$ bcde \\
\hline $\mathrm{R} \times 60$ & $7.0 \pm 1.53 \mathrm{bc}$ & $14.6 \pm 0.13^{\text {cdefg }}$ & $3.74 \pm 0.01^{\mathrm{fgh}}$ & $5.2 \pm 0.07$ cde & $2.1 \pm 0.15^{\mathrm{abcd}}$ & $0.28 \pm 0.02^{a b c d}$ \\
\hline NT 112 & $6.1 \pm 1.53^{b c d}$ & $14.7 \pm 0.13^{\text {abcde }}$ & $3.79 \pm 0.01 \mathrm{bcd}$ & $5.3 \pm 0.07^{\mathrm{bcd}}$ & $2.3 \pm 0.15^{a b c}$ & $0.31 \pm 0.02^{\mathrm{ab}}$ \\
\hline$p$ & $<0.0001$ & 0.004 & $<0.0001$ & $<0.0001$ & 0.142 & $<0.0001$ \\
\hline
\end{tabular}

${ }^{1}$ Spontaneous alcoholic fermentation. Each value represents the mean of three replicates ( \pm standard error of the mean). Means in columns followed by different letters are significantly different $(p \leq 0.05)$.

Not all the Merlot wines fermented to dryness, particularly the spontaneous alcoholic treatment contained high residual sugar levels (Table 2). The ethanol content ranged from 14.2 to $15.1 \%$ in the smoked wines, with the QA23 treatment having the highest levels. The TA ranged between 4.8 and $5.9 \mathrm{~g} / \mathrm{L}$, and varied significantly among the yeasts. 
Malic acid levels varied between 1.8 and $2.3 \mathrm{~g} / \mathrm{L}$. The VA varied between 0.20 and $0.33 \mathrm{~g} / \mathrm{L}$ for the wines produced with different yeasts.

\subsubsection{Small-Scale Wine Production Trial}

The enological parameters of the smoked and unsmoked Chenin Blanc wines are reported in Table 3. The ethanol content ranged from 12.8 to $13.6 \%$, with the smoked wines showing lower ethanol levels than the control wines (no smoke exposure). Ristic et al. [11] reported the same trend. The TA varied between 5.5 and $6.2 \mathrm{~g} / \mathrm{L}$ for the smoked wines compared to 5.6 and 5.9 for the control wines. However, for wines produced with QA23 and VIN 13, the TA was marginally higher in the control wines compared to the smoked wines. This trend of the control wines having higher TA levels than the smoked wines was also noted by Ristic et al. [11]. The VA levels varied significantly among the yeasts, with the smoked wines containing similar or lower levels than the control wines. Ristic et al. [11] reported the opposite trend, with the smoked wines containing higher VA levels than the unsmoked wines. The reasons for the differences in the ethanol, TA and the VA levels between the smoked and unsmoked wines are unclear and needs further investigation.

Table 3. Enological parameters and probability $(p)$ values of Chenin Blanc wines produced from smoked and unsmoked juice using three commercial wine yeasts.

\begin{tabular}{|c|c|c|c|c|c|c|}
\hline Treatment & $\begin{array}{c}\text { Residual Sugar } \\
(\mathrm{g} / \mathrm{L})\end{array}$ & $\begin{array}{l}\text { Ethanol } \\
(\% v / v)\end{array}$ & $\mathrm{pH}$ & $\begin{array}{l}\text { Total Acidity } \\
\text { (g/L) }\end{array}$ & $\begin{array}{l}\text { Malic Acid } \\
\text { (g/L) }\end{array}$ & $\begin{array}{c}\text { Volatile } \\
\text { Acidity }(\mathrm{g} / \mathrm{L})\end{array}$ \\
\hline QA $23\left(C^{1}\right)$ & $1.4 \pm 0.35^{a}$ & $13.3 \pm 0.17^{a b c}$ & $3.46 \pm 0.02^{a b}$ & $5.6 \pm 0.17^{b}$ & $1.5 \pm 0.10^{\mathrm{a}}$ & $0.23 \pm 0.01^{b}$ \\
\hline QA $23\left(S^{2}\right)$ & $1.0 \pm 0.35^{\mathrm{a}}$ & $12.9 \pm 0.17 \mathrm{bc}$ & $3.45 \pm 0.02 \mathrm{ab}$ & $5.5 \pm 0.17^{b}$ & $1.4 \pm 0.10^{\mathrm{a}}$ & $0.19 \pm 0.01^{\mathrm{c}}$ \\
\hline VIN $13(\mathrm{C})$ & $0.7 \pm 0.35^{\mathrm{a}}$ & $13.6 \pm 0.17^{a}$ & $3.46 \pm 0.02 \mathrm{ab}$ & $5.9 \pm 0.17^{\mathrm{ab}}$ & $1.6 \pm 0.10^{a}$ & $0.17 \pm 0.01^{c}$ \\
\hline VIN 13 (S) & $0.3 \pm 0.35^{\mathrm{a}}$ & $13.3 \pm 0.17^{\mathrm{ab}}$ & $3.43 \pm 0.02^{b}$ & $5.6 \pm 0.17^{b}$ & $1.5 \pm 0.10^{\mathrm{a}}$ & $0.17 \pm 0.01^{c}$ \\
\hline $\mathrm{X} 16(\mathrm{C})$ & $1.9 \pm 0.35^{\mathrm{a}}$ & $12.9 \pm 0.17^{b c}$ & $3.48 \pm 0.02^{\mathrm{a}}$ & $5.9 \pm 0.17^{a b}$ & $1.5 \pm 0.10^{\mathrm{a}}$ & $0.27 \pm 0.01^{a}$ \\
\hline X16 (S) & $1.3 \pm 0.35^{\mathrm{a}}$ & $12.8 \pm 0.17^{\mathrm{c}}$ & $3.43 \pm 0.02^{b}$ & $6.2 \pm 0.17^{a}$ & $1.6 \pm 0.10^{a}$ & $0.24 \pm 0.01 \pm$ \\
\hline$p$ & 0.851 & 0.021 & 0.131 & 0.071 & 0.570 & $<0.0001$ \\
\hline
\end{tabular}

${ }^{1} \mathrm{C}$ : Control, no smoke exposure, ${ }^{2} \mathrm{~S}$ : Smoke treatment. Each value represents the mean of three replicates ( \pm standard error of the mean). Means in columns followed by different letters are significantly different $(p \leq 0.05)$.

\subsection{Volatile Phenol Analyses}

\subsubsection{Laboratory-Scale Yeast Trials}

The correlation between the volatile phenols of smoked Chenin Blanc wines and the various yeast treatments is shown in Figure 1. The PCA biplot of the 10 variables (volatile phenols) explains $86.82 \%$ ( $\mathrm{PC} 1=76.38 \%$ and $\mathrm{PC} 2=10.44 \%$ ) of the variance in the data set. The clustering indicates that the volatile phenol levels varied in the wines produced with the different yeast strains from the same base juice. The concentrations of the various volatile phenols of the Chenin Blanc wines are listed in Table S1. Wines produced with QA23 showed a positive association with guaiacol $(15.15 \mu \mathrm{g} / \mathrm{L})$, 4-methylguaiacol $(12.58 \mu \mathrm{g} / \mathrm{L})$, 4-ethylguaiacol $(5.36 \mu \mathrm{g} / \mathrm{L})$, phenol $(29.89 \mu \mathrm{g} / \mathrm{L}), p$-cresol $(5.00 \mu \mathrm{g} / \mathrm{L})$ and eugenol $(1.46 \mu \mathrm{g} / \mathrm{L})$, and contained the highest levels of the respective volatile phenols (Figure 1 and Table S1). QA23 is a yeast known to have $\beta$-glucosidase activity [22], which should lead to higher levels of volatile phenols in the presence of conjugated phenols. AWRI R2, VIN 7, BM4X4, Cross Evolution and Rhone 4600 also showed a positive association with the unwanted volatile phenols (Figure 1). While VIN 13, X16, UOA Maxithiol, X5, $\mathrm{BDX}$ and the spontaneous alcoholic fermentation displayed a negative correlation with the volatile phenols. The lowest guaiacol concentrations were observed in wines fermented with VIN $13(10.90 \mu \mathrm{g} / \mathrm{L})$ and X16 (10.82 $\mu \mathrm{g} / \mathrm{L})$ (Table S1). 


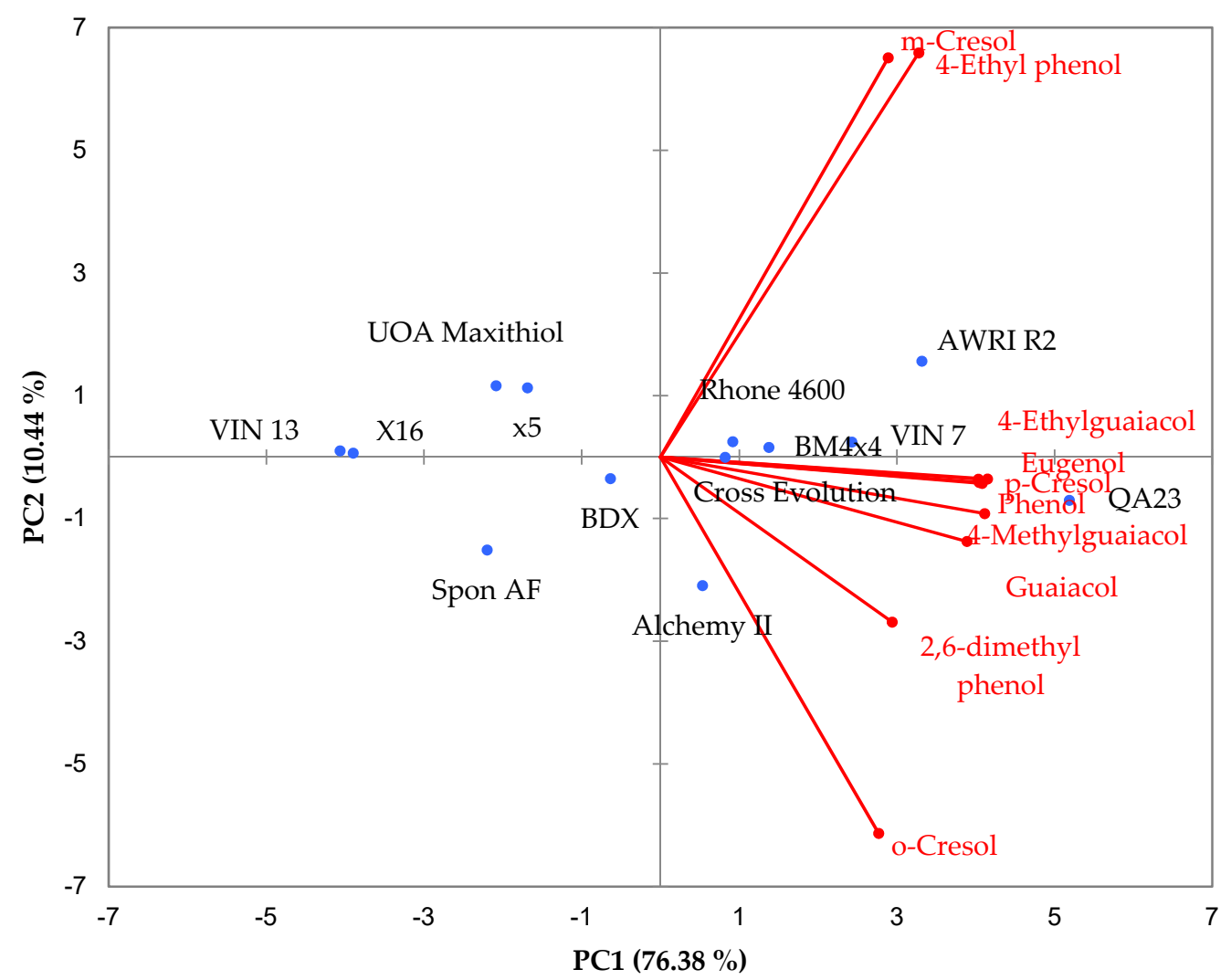

Figure 1. Principal component biplot of volatile phenols in laboratory-scale Chenin Blanc wines produced from juice exposed to smoke and fermented with different commercial wine yeasts. Mean values of three replicate fermentations and yeast details are included in the materials and methods. Abbreviation: Spon AF = Spontaneous alcoholic fermentation.

The correlation of volatile phenol levels of smoked Merlot wines produced with different yeasts are shown in Figure 2. The PCA biplot explains $74.32 \%(\mathrm{PC} 1=58.60 \%$ and $\mathrm{PC} 2=15.72 \%$ ) of the variance in the data set. As observed with the Chenin Blanc wines, the volatile phenol levels varied in the Merlot wines produced with the different yeast strains. Wines that underwent spontaneous alcoholic fermentation showed a positive association with guaiacol $(8.21 \mu \mathrm{g} / \mathrm{L})$, 4-methylguaiacol $(4.56 \mu \mathrm{g} / \mathrm{L})$, 4-ethylguaiacol $(2.35 \mu \mathrm{g} / \mathrm{L})$, 4ethylphenol $(0.77 \mu \mathrm{g} / \mathrm{L}), 2,6$-dimethyl phenol $(1.81 \mu \mathrm{g} / \mathrm{L}), o$-cresol $(2.38 \mu \mathrm{g} / \mathrm{L})$ and $p$-cresol $(2.25 \mu \mathrm{g} / \mathrm{L})$, and contained the highest concentrations of most of these volatile phenols (Figure 2 and Table S2). D254, Clos, NT 50, QA23, Exence, D21 and AWRI 796 showed a positive association with most of the volatile phenols (Figure 2). While NT 112, NT 202, RX60, FX10, D80, WE 372, VIN 13 and BDX displayed a negative correlation with most the volatile phenols. However, VIN 13, NT 112 and NT 202 showed a positive association with $m$-cresol. The lowest guaiacol concentrations were observed in wines fermented with NT $112(6.46 \mu \mathrm{g} / \mathrm{L}), \mathrm{RX} 60(6.55 \mu \mathrm{g} / \mathrm{L})$ and WE $372(6.55 \mu \mathrm{g} / \mathrm{L})$, and contained significantly lower levels than wines produced with spontaneous fermentation and D254 (Table S2). Yeast strain D254 produced high guaiacol levels compared to the other yeasts used in this study, which is in agreement with the findings of Ristic et al. [11]. BDX did not produce high volatile phenol levels, which is also in agreement with the findings of Ristic et al. [11]. 


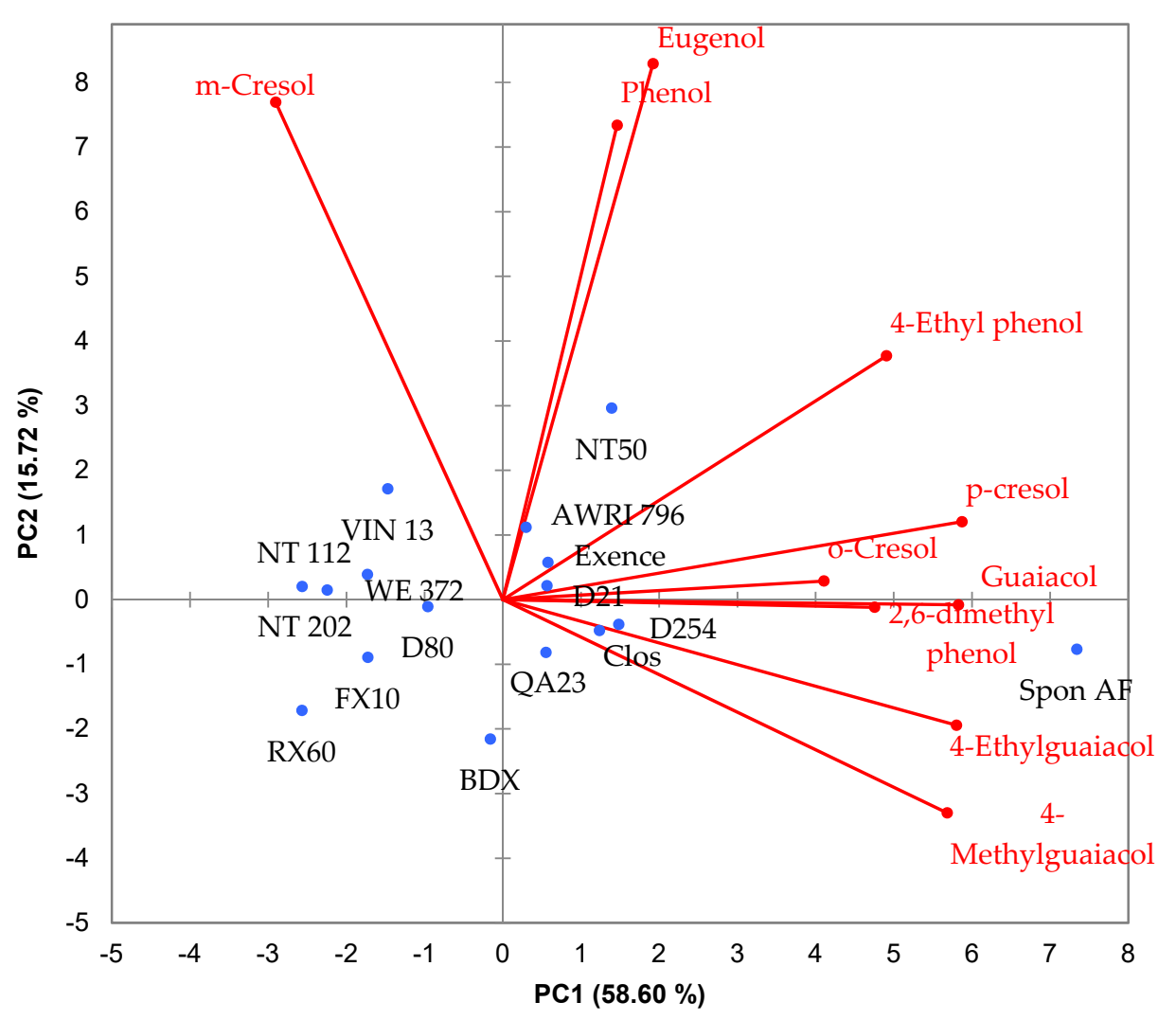

Figure 2. Principal component biplot of volatile phenols in laboratory-scale Merlot wines produced from juice exposed to smoke and fermented with different commercial wine yeasts. Mean values of three replicate fermentations and yeast details are included in the materials and methods. Abbreviation: Spon AF = Spontaneous alcoholic fermentation.

Based on the two datasets it would appear that smoked juice can be used to screen yeasts for suitability for use in wine production from smoke affected grapes. The laboratoryscale trials indicate that the yeasts VIN 13 and X16 may be more suitable for wine production from smoke-affected Chenin Blanc grapes, than other yeast strains, while RX60 and NT 112 should be considered for wine production of smoke-affected Merlot grapes. However, further research is needed to support preliminary findings before definitive recommendations can be made.

\subsubsection{Small-Scale Wine Production Trial}

In the laboratory-scale Chenin Blanc trial, VIN 13 and X16 appeared to be good candidates for further investigation, due to their association with lower volatile phenol levels, while QA23 associated with high levels of volatile phenols and could serve as a negative control (Figure 1). The correlation between the volatile phenol levels of smoked and the unsmoked wines fermented with QA23, VIN 13 and X16 during the small-scale wine production trial, is shown in Figure 3. The PCA biplot explains $93.36 \%$ (PC1 $=84.11 \%$ and PC2 $=9.25 \%$ ) of the variance in the data set. Except for smoked wines fermented with VIN 13, there was a clear separation of smoked and unsmoked wines. The wines produced from smoked juice contained significantly higher levels of volatile phenols than the control wines (Figure 3 and Table S3). The same trend was observed as in the laboratory-scale yeast trial, where the volatile phenol levels varied in the wines produced with different yeasts. The control wines contained low or undetectable levels of the various volatile phenols. Smoked wines fermented with QA23 and X16, showed a positive association with guaiacol, 4-methylguaiacol, 4-ethylguaiacol, 4-ethylphenol, o-cresol and eugenol (Figure 3). While smoked wines fermented with VIN 13 showed a negative association with the aforementioned volatile phenols. These results are in agreement with the trend observed 
in the laboratory-scale trial for the yeasts VIN 13 and QA23, where wines produced from smoke-exposed juice and fermented with QA23 was associated with high volatile phenol levels, while VIN 13 wines correlated with lower volatile phenol levels. Contrary to the laboratory-scale trial, smoked juice that was fermented with X16 resulted in wines with high volatile phenol levels.

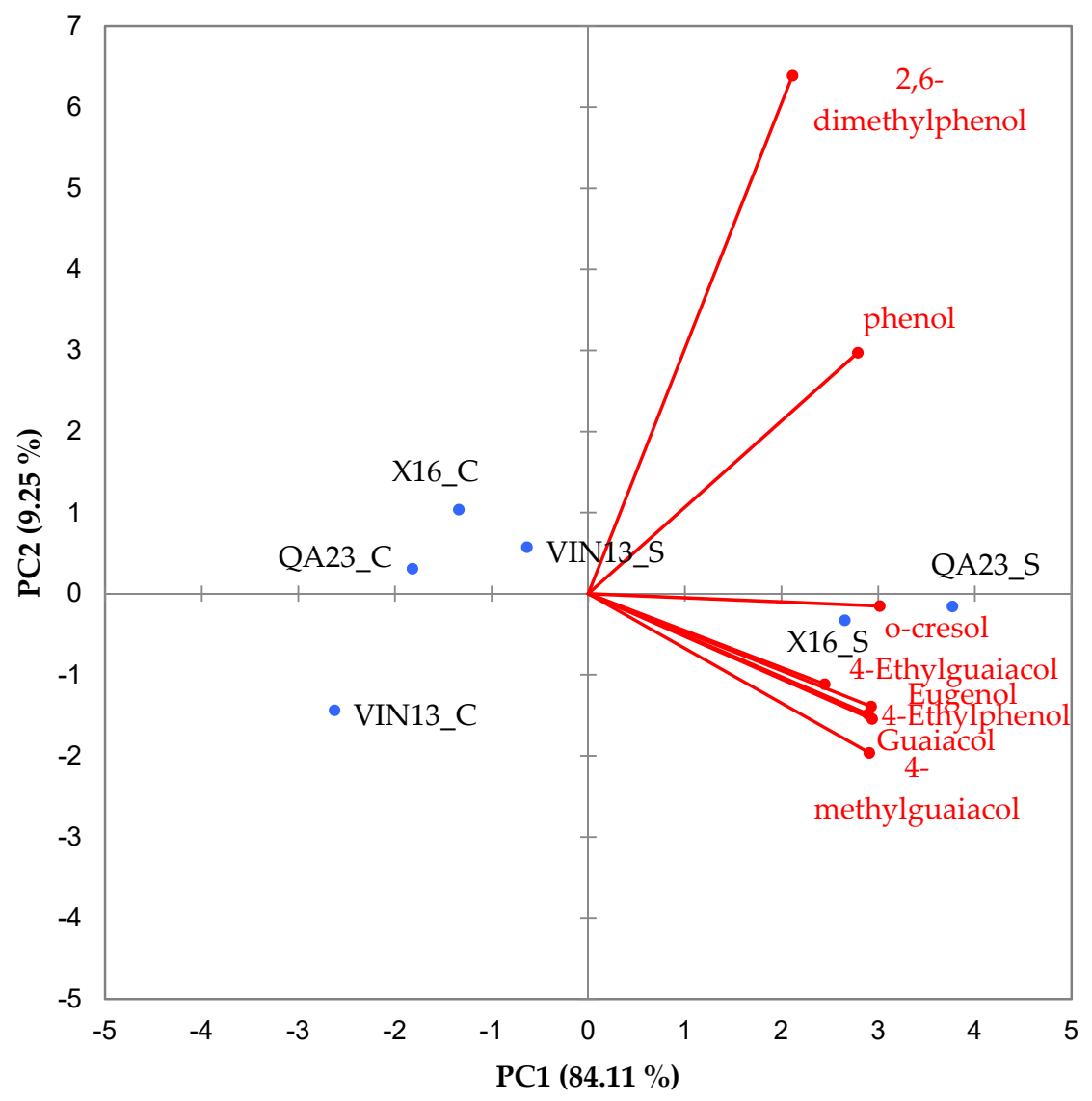

Figure 3. Principal component biplot of volatile phenols in small-scale Chenin Blanc wines produced from smoked (S) and unsmoked (C) juice fermented with three commercial wine yeasts. Mean values of three replicate fermentations and yeast details are included in the materials and methods.

The small-scale Chenin Blanc trial showed that juice exposed to smoke resulted in wines with higher levels of volatile phenols than the control wines. This indicates that the smoke treatment applied to the juice increased the volatile phenol levels in the juice and the wines (Table S3). The results of this study are comparable to those reported by Ristic et al. [11], where the grapes were smoked on the vines. Guaiacol levels ranged between 5.3 and $12.9 \mu \mathrm{g} / \mathrm{L}$ in the yeast trial conducted by Ristic et al. [11]. While in this study guaiacol levels in the laboratory-scale Chenin Blanc trials ranged between 10.82 and $15.15 \mu \mathrm{g} / \mathrm{L}$, between 6.46 and $8.21 \mu \mathrm{g} / \mathrm{L}$ in the Merlot trial and between 1.98 and $4.76 \mu \mathrm{g} / \mathrm{L}$ for the small-scale Chenin Blanc trial. However, the levels of volatile phenols in this study were not as high as those found in commercial wines produced from grapes exposed to wild or vineyard fires [18]. Multiple smoke applications to the juice or longer exposure times could possibly increase the levels of volatile phenols. Despite the limitation of applying smoke directly to the juice, this method is an easy and quick alternative to impart volatile phenols into juice, and can be used to investigate the effect of yeast strains, lactic acid bacteria treatments and even amelioration strategies on the levels of volatile phenols.

This study showed that there are notable variations in the levels of volatile phenols produced by different yeast strains and that yeast selection plays an important role in the 
volatile phenol levels of wines. Therefore, more research is needed to determine which commercial yeast strains are suitable for wine production from smoked-exposed grapes.

\subsection{Sensory Evaluations}

The results of the triangle tests of the Chenin Blanc wines are listed in Table 4 . The judges could distinguish between the smoked and control wines $(p \leq 0.05)$ despite the levels of volatile phenols being well below their respective ODT values. The ODT of guaiacol is $23 \mu \mathrm{g} / \mathrm{L}$ and is associated with burnt, smoky, toasty, phenolic characteristics [13]; $21 \mu \mathrm{g} / \mathrm{L}$ for 4-methylguaiacol, perceived as sweet-spicy, phenolic and leathery [23]; and $62 \mathrm{\mu g} / \mathrm{L}$ for o-cresol, linked with burnt, smoky, medicinal and tar odors. The panel also observed subtle color differences between the smoked and unsmoked wines. For all the treatments, the panel preferred the control wines that were unsmoked. None of the yeast were effective in masking the negative flavors associated with smoked wines, but the flavor profiles of the wines differed.

Table 4. Triangle test and preference results of smoked and unsmoked Chenin Blanc wines produced with different yeast strains.

\begin{tabular}{|c|c|c|c|}
\hline & \multicolumn{3}{|c|}{ Treatment } \\
\hline & QA23 & VIN 13 & X16 \\
\hline $\begin{array}{l}\text { Number of correct judges } \\
\qquad(n=18)\end{array}$ & 13 & 13 & 10 \\
\hline Probability value * & 0.001 & 0.001 & 0.043 \\
\hline Preferred treatment & $\begin{array}{c}\text { Unsmoked } \\
78\end{array}$ & $\begin{array}{c}\text { Unsmoked } \\
71\end{array}$ & $\begin{array}{c}\text { Unsmoked } \\
76\end{array}$ \\
\hline $\begin{array}{c}\text { Comments about smoked } \\
\text { wines }\end{array}$ & $\begin{array}{l}\text { Smoky, sulfur and } \\
\text { vegetative }\end{array}$ & $\begin{array}{c}\text { Ashy, chalky, } \\
\text { metallic and smoky }\end{array}$ & $\begin{array}{l}\text { Brussel sprouts, } \\
\text { cabbage, onions, oily } \\
\text { and sulfur }\end{array}$ \\
\hline
\end{tabular}

* Probability value $(p) \leq 0.05$ indicate significant differences. ${ }^{* *}$ Percentage judges that preferred the treatment.

Smoked wines presented smoky, sulfur, vegetative and cooked vegetable characteristics, which are in agreement with the findings of McKay et al. [18,24]. These authors reported that synergistic interactions between volatile phenols at peri- or sub-threshold levels could be correlated to negative sensory attributes in some wines. McKay et al. [24] also showed that volatile phenols interacted with other volatile compounds, which may have a positive or negative impact the sensory attributes of the wines. Positive characteristics in wine like fruity and sweet attributes can be reduced as a result of the interactions of low levels of phenols, 2-iso-butyl-3-methoxypyrazine and 2,4,6-trichloroanisole [24].

Even though the yeasts selected in this trial were not effective in masking the negative flavors associated smoked wines, other yeast strains might produce different results. Therefore, more research is needed, where different yeast strains and grape varieties are evaluated and especially, how the volatile phenols are metabolized by different yeast strains.

\section{Conclusions}

The levels of volatile phenols in wines produced with different commercial yeast strains varied considerably. Smoked wines contained significantly higher levels of volatile phenols than unsmoked wines. Volatile phenols can have a negative effect on wine flavor, even at levels below their ODT. Yeast selection can affect the volatile phenol levels and flavor profiles of wines. Yeast selection may, therefore, be a means to reduce the levels of volatile phenols in wines, but it may not be able to mask the negative flavors associated with these volatile phenols. This study also showed that juice can be smoked instead of grapes, making it easier to conduct smoke associated research. Further research is needed to investigate the volatile and glyconjugated phenols, as well as longer smoke exposure applications to obtain higher levels of volatile phenols in wines. How volatile phenols 
are metabolized by the different yeast strains and how yeast selection affects wine quality when the levels of volatile or glycoconjugated phenols in the grapes or juice are high, also need further investigation.

Supplementary Materials: The following are available online at https:/ /www.mdpi.com/article/10 $.3390 /$ fermentation7040240/s1. Table S1. Volatile phenol analyses of smoked Chenin Blanc wines produced from smoked juice using different commercial wine yeasts; Table S2. Volatile phenol analyses of smoked Merlot wines produced from smoked juice using different commercial wine yeasts; Table S3. Volatile phenol analyses of Chenin Blanc wines produced from unsmoked and smoked juice three commercial wine yeasts.

Author Contributions: Conceptualization, H.W.d.P. and N.P.J.; methodology, H.W.d.P., J.W.H. and L.M.; formal analysis, H.W.d.P., J.W.H. and L.M.; statististical analyses, H.W.d.P. and M.v.d.R.; investigation, H.W.d.P.; resources, H.W.d.P. and N.P.J; data curation, H.W.d.P.; writing-original draft preparation, H.W.d.P.; writing—review and editing, N.P.J., J.W.H., M.v.d.R. and L.M.; project administration, H.W.d.P.; funding acquisition, H.W.d.P. All authors have read and agreed to the published version of the manuscript.

Funding: This research was funded by Winetech, South Africa and the Agricultural Research Council (ARC) of South Africa.

Institutional Review Board Statement: No institutional review board, but ethical review and approval was obtained for this study.

Informed Consent Statement: Informed consent was obtained from all subjects involved in the study.

Data Availability Statement: Data are contained within the article.

Acknowledgments: The authors would like to thank the ARC for providing infrastructure and resources. The authors also thank all the students, interns, technicians and research assistants who contributed.

Conflicts of Interest: The authors declare no conflict of interest.

\section{References}

1. Mirabelli-Montan, Y.A.; Marangon, M.; Graça, A.; Mayr Marangon, C.M.; Wilkinson, K.L. Techniques for mitigating the effects of smoke taint while maintaining quality in wine production: A review. Molecules 2021, 26, 1672. [CrossRef]

2. Brodison, K. Effect of Smoke in Grape and Wine Production; Department of Agriculture and Food: Western Australia, Perth, 2013; Bulletin 4847.

3. Congressional Research Service. Wildfire Statistics. Available online: https://fas.org/sgp/crs/misc/IF10244.pdf (accessed on 1 June 2021).

4. Kennison, K.R.; Wilkinson, K.L.; Williams, H.G.; Smith, J.H.; Gibberd, M.R. Smoke-derived taint in wine: Effect of postharvest smoke exposure of grapes on the chemical composition and sensory characteristics of wine. J. Agric. Food Chem. 2007, 55, 10897-10901. [CrossRef] [PubMed]

5. Kennison, K.R.; Gibberd, M.R.; Pollnitz, A.P.; Wilkinson, K.L. Smoke-derived taint in wine: The release of smoke-derived volatile phenols during fermentation of Merlot juice following grapevine exposure to smoke. J. Agric. Food Chem. 2008, 56, 7379-7383. [CrossRef]

6. Krstic, M.P.; Johnson, D.L.; Herderich, M.J. Review of smoke taint in wine: Smoke-derived volatile phenols and their glycosidic metabolites in grapes and vines as biomarkers for smoke exposure and their role in the sensory perception of smoke taint. Aust. J. Grape Wine Res. 2015, 21, 537-553. [CrossRef]

7. Kennison, K.R.; Wilkinson, K.L.; Pollnitz, A.P.; Williams, H.G.; Gibberd, M.R. Effect of timing and duration of grapevine exposure to smoke on the composition and sensory properties of wine. Aust. J. Grape Wine Res. 2009, 15, 228-237. [CrossRef]

8. Kennison, K.R.; Wilkinson, K.L.; Pollnitz, A.P.; Williams, H.G.; Gibberd, M.R. Effect of smoke application to field-grown Merlot grapevines at key phenological growth stages on wine sensory and chemical properties. Aust. J. Grape Wine Res. 2011, 17, S5-S12. [CrossRef]

9. Ristic, R.; Boss, P.K.; Wilkinson, K.L. Influence of fruit maturity at harvest on the intensity of smoke taint in wine. Molecules 2015, 20, 8913-8927. [CrossRef]

10. Ristic, R.; Fudge, A.L.; Pinchbeck, K.A.; De Bei, R.; Fuentes, S.; Hayasaka, Y.; Tyerman, S.D.; Wilkinson, K.L. Impact of grapevine exposure to smoke on vine physiology and the composition and sensory properties of wine. Theor. Exp. Plant. Phys. 2016, 28, 67-83. [CrossRef] 
11. Ristic, R.; Osidacz, P.; Pinchbeck, K.; Hayasaka, Y.; Fudge, A.; Wilkinson, K. The effect of winemaking techniques on the intensity of smoke taint in wine. Aust. J. Grape Wine Res. 2011, 17, S29-S40. [CrossRef]

12. Kelly, D.; Zerihun, A.; Hayasaka, Y.; Gibberd, M. Winemaking practice affects the extraction of smokeborne phenols from grapes into wines. Aust. J. Grape Wine Res. 2014, 20, 386-393. [CrossRef]

13. Parker, M.; Osidacz, P.; Baldock, G.; Hayasaka, Y.; Black, C.; Pardon, K.; Jeffery, D.; Geue, J.; Herderich, M.; Francis, I. Contribution of several volatile phenols and their glycoconjugates to smoke-related sensory properties of red wine. J. Agric. Food Chem. 2012, 60, 2629-2637. [CrossRef] [PubMed]

14. Spillman, P.J.; Iland, P.G.; Sefton, M.A. Accumulation of volatile oak compounds in a model wine stored in American and Limousin oak barrels. Aust. J. Grape Wine Res. 1998, 4, 67-73. [CrossRef]

15. Jolly, N.P.; Augustyn, O.P.H.; Pretorius, I.S. The role and use of non-Saccharomyces yeasts in wine production. S. Afr. J. Enol. Vitic. 2006, 27, 15-39. [CrossRef]

16. Swiegers, J.H.; Pretorius, I.S. Yeast modulation of wine flavour. Adv. Appl. Microbiol. 2005, 57, 131-175. [PubMed]

17. De Vries, C.; Mokwena, L.; Buica, A.; McKay, M. Determination of volatile phenols in Cabernet Sauvignon wines, made from smoke-affected grapes, by using HS-SPME GC-MS. S. Afr. J. Enol. Vitic. 2016, 37, 15-21. [CrossRef]

18. McKay, M.; Bauer, F.F.; Panzeri, V.; Mokwena, L.; Buica, A. Profiling potentially smoke tainted red wines: Volatile phenols and aroma attributes. S. Afr. J. Enol. Vitic. 2019, 40,1-16.

19. Randall, J.H. Triangular Test Analysis; Internal Report; Stellenbosch University: Stellenbosch, South Africa, 1998.

20. Roessler, E.B.; Pangborn, R.M.; Sidel, J.L.; Stone, H. Expanded statistical tables for estimating significance in paired-Preference, paired-difference, duo-trio and triangle tests. J. Food Sci. 1978, 43, 940-943. [CrossRef]

21. South African Liquor Products Act 60 of 1989, Regulations. Table 2: Classes for Wine and Specific Requirements for Classes. Available online: http:/ / www.sawis.co.za/winelaw/southafrica.php (accessed on 23 August 2021).

22. Lallemand Oenology Catologue. Available online: https://www.lallemandwine.com/en/china/products/catalogue/wineyeasts / 27/lalvin-qa23/ (accessed on 23 August 2021).

23. Czerny, M.; Christlbauer, M.; Fischer, A.; Granvogl, M.; Hammer, M.; Hartl, C.; Hernandez, N. Re-investigation on odour thresholds of key food aroma compounds and development of an aroma language based on odour qualities of defined aqueous odorant solutions. Eur. Food Res. Techn. 2008, 228, 265-273. [CrossRef]

24. McKay, M.; Bauer, F.F.; Panzeri, V.; Buica, A. Investigation of olfactory interactions of low levels of five off-flavour causing compounds in a red wine matrix. Food Res. Int. 2020, 128, 108878. [CrossRef] [PubMed] 